\title{
Mesorhizobium shangrilense sp. nov., isolated from root nodules of Caragana species
}

\author{
Yang Li Lu, ${ }^{1}$ Wen Feng Chen, ${ }^{1}$ En Tao Wang, ${ }^{2}$ Li Li Han, ${ }^{1}$ \\ Xiao Xia Zhang, ${ }^{3}$ Wen Xin Chen ${ }^{1}$ and Su Zhen $\mathrm{Han}^{4}$
}

\author{
Correspondence \\ Wen Feng Chen \\ chenwf@cau.edu.cn
}

\author{
${ }^{1}$ State Key Laboratories for Agro biotechnology/College of Biological Sciences, China Agricultural \\ University, Beijing 100193, PR China \\ ${ }^{2}$ Departamento de Microbiología, Escuela Nacional de Ciencias Biológicas, Instituto Politécnico \\ Nacional, México D. F. 11340, Mexico \\ ${ }^{3}$ Agricultural Cultural Collection of China, Institute of Agricultural Resources and Regional Planning, \\ Chinese Academy of Agricultural Sciences, Beijing 100081, PR China \\ ${ }^{4}$ College of Life Science, Capital Normal University, Beijing 100037, PR China
}

Caragana is a genus of about 100 species of flowering plants in the family Leguminosae, native to north-eastern Europe, Russia, central Asia, the Himalayas and China. Members of this genus have been introduced into many regions in northern latitudes because of their remarkable cold- and drought-resistant properties and nitrogen-fixing ability. Approximately 70 species have been recorded in China and most of them grow on hills and in gullies, thickets, plains and plateaux (Zhang, 2005). They are ecologically important because they serve as forage resources for wild animals and are preferred plants for

Abbreviations: MP, maximum-parsimony; $\mathrm{NJ}$, neighbour-joining.

The GenBank/EMBL/DDBJ accession numbers for the partial $16 S$ rRNA, atpD, recA, glnll, nodC and nifH gene sequences of strain CCBAU 65327 ${ }^{\top}$ are EU074203, EU672471, EU672501, EU672486, EU687487 and EU877532, respectively.

Fatty acid profiles, sequence similarities, nodC and nifH gene phylogenetic trees and a phenogram derived from UPGMA/S $S_{\mathrm{SM}}$ analysis and SDS-PAGE analysis of whole-cell soluble proteins of strains from Mesorhizobium shangrilense sp. nov. and related species are available as supplementary material with the online version of this paper. use in reforestation against desertification and erosion (Fan et al., 2007; Su et al., 2005). Most of the rhizobia associated with Caragana belong to the genus Mesorhizobium (Chen et al., 1995; Guan et al., 2008; Lu et al., 2009; Yan et al., 2007) and two species, Mesorhizobium tianshanense and Mesorhizobium caraganae, have been described so far (Chen et al., 1995; Guan et al., 2008).

During the study of rhizobia nodulating Caragana species from three different regions of China, 144 strains (of a total of 174) were characterized and classified in the genus Mesorhizobium based on 16S rRNA gene sequence analysis, BOX-PCR fingerprinting and SDS-PAGE profiles of wholecell soluble proteins ( $\mathrm{Lu}$ et al., 2009). Five of the isolates from nodules of Caragana bicolor and Caragana erinacea grown in Yunnan Province of China exhibited distinct characteristics and differed from the known species of Mesorhizobium. Therefore, in the present study these five strains were analysed further and compared with the species within the genus Mesorhizobium on the basis of phenotypic, genotypic, phylogenetic and symbiotic characteristics to determine their species status. 
Rhizobia isolated from root nodules were purified by a standard procedure on YMA medium (Vincent, 1970), and isolates were maintained on YMA (Vincent, 1970) at $4{ }^{\circ} \mathrm{C}$ for temporary storage and in $20 \%$ glycerol at $-70{ }^{\circ} \mathrm{C}$ for long-term storage.

Approximately $1350 \mathrm{bp}$ of the $16 \mathrm{~S}$ rRNA gene was amplified and sequenced for each of the five strains using primers $\mathrm{P} 1$ and $\mathrm{P} 6$ according to the procedure of Tan et al. (1997). The sequences were aligned with those of related Mesorhizobium species using the CLUSTAL W program in the MEGA 4.0 software package (Tamura et al., 2007). Aligned sequences were analysed by using the MEGA software to produce a Jukes-Cantor distance (Jukes \& Cantor, 1969) and to construct an optimal unrooted tree using the neighbour-joining (NJ) (Saitou \& Nei, 1987) method and maximum-parsimony (MP). The robustness of the tree topology was calculated from bootstrap analysis using 1000 replications of the sequences (Felsenstein, 1985). All five strains had identical $16 \mathrm{~S}$ rRNA gene sequences that were closely related to those of M. loti LMG $6125^{\mathrm{T}}$ and M. ciceri $\mathrm{UPM}-\mathrm{Ca}^{\mathrm{T}}$, with $99.7 \%$ similarity (Supplementary Table S1 available in IJSEM Online). Percentages of $16 S$ rRNA gene sequence similarity between the new isolates and the type strains of species of the genus Mesorhizobium, where values are higher than $97 \%$, are shown in Supplementary Table S1. Relationships revealed by two cluster methods (NJ and MP) were similar and the NJ tree is shown in Fig. 1a.

All five strains and the closely related reference strains of Mesorhizobium species were subjected to SDS-PAGE analysis of whole-cell soluble proteins, as described previously (Tan et al., 1997). The normalized densitometric traces of the electrophoretic protein patterns were grouped using the Gelcompar II software package (Applied Maths). The similarity between each pair of samples (strains) was expressed by using the Dice coefficient and a UPGMA dendrogram was reconstructed (Vauterin \& Vauterin, 1992). The strikingly similar protein patterns observed among the five novel strains indicated their considerable homogeneity (Supplementary Fig. S1). However, they were not clones, because they were isolated from different sampling sites and different species of Caragana (Table 1). Comparison of the protein patterns with those of other related Mesorhizobium species showed that these were not similar to the new group (Supplementary Fig. S1).

Sequence analyses included housekeeping genes atpD (encoding ATP synthase beta subunit, approx. $510 \mathrm{bp}$ ) and $r e c A$ (homologous recombination protein $\mathrm{A}$, approx. $530 \mathrm{bp}$ ), amplified according to Gaunt et al. (2001), and a $660 \mathrm{bp}$ intragenic fragment of $g \operatorname{lnII}$ amplified according to Turner \& Young (2000). NJ trees of these genes (Fig. 1b-d) showed that the groupings and precise branching patterns in these trees were similar, but not entirely consistent with those based on the 16S rRNA gene. The five novel strains have highly similar or identical atpD, recA and glnII sequences, and sequence similarities with the most related
Mesorhizobium species were clearly lower than those found among other accepted Mesorhizobium species (Supplementary Table S1).

The symbiotic genes (nod and nif) of rhizobia are adaptive genes that have, in many cases, an evolutionary history independent of the housekeeping genes (Wang et al., 2007). Comparison of their phylogenies with those derived from housekeeping genes may reveal events of lateral gene transfer among rhizobial symbiotic genes (Chen et al., 2008; Haukka et al., 1998; Liu et al., 2005). In this study, partial sequences of the symbiotic genes nodC (approx. $900 \mathrm{bp}$ ) and nifH (approx. $760 \mathrm{bp}$ ) from the five novel strains were amplified by using primers (nodCF and nodCI, nifHF and nifHI) and PCR conditions described by Laguerre et al. (2001). In the phylogenetic trees based on nodC and nifH genes (Supplementary Fig. S2a, b), the four novel strains isolated from $C$. bicolor had identical sequences, while strain CCBAU 65336 that was isolated from $C$. erinacea was a little different. Comparison of the phylogenetic trees reconstructed on the basis of housekeeping and symbiotic genes (Fig. 1 and Fig. S2) demonstrated the different evolutionary histories of these genes and the close relationship between the symbiotic genes and their host plants suggested by Ueda et al. (1995).

High similarities (>96.2\%; Supplementary Table S1) of symbiotic genes among the Caragana mesorhizobia and the type strains of Mesorhizobium temperatum, Mesorhizobium septentrionale and Mesorhizobium tianshanense indicate that they may have common host ranges, as suggested by Laguerre et al. (2001) and Chen et al. (2008). To test whether the Caragana mesorhizobia share the same hosts as these three species, cross-inoculation tests between the above Mesorhizobium species and their original hosts were performed. Seed treatment and inoculation of Caragana species, Astragalus adsurgens and other common legumes were performed using the standard method of Vincent (1970), except that seeds of Glycyrrhiza uralensis were firstly immersed in concentrated sulfuric acid for $4 \mathrm{~h}$ before surface-sterilization. Seedlings inoculated with different strains were grown in a greenhouse under natural daylight for 6 weeks. Non-inoculated control seedlings were cultured under the same conditions. The results confirmed that each of the five strains from Caragana and the three type strains ( $M$. tianshanense, $M$. temperatum and M. septentrionale) could form effective nodules on the hosts Glycyrrhiza uralensis, Caragana microphylla, Caragana intermedia and Astragalus adsurgens. The representative strain CCBAU $65327^{\mathrm{T}}$ of the novel Mesorhizobium group was further used for cross-nodulation tests with another 12 legume species. Results showed that Phaseolus vulgaris, Vigna unguiculata and Vigna radiata could nodulate with CCBAU $65327^{\mathrm{T}}$, while no nodules were found on the CCBAU $65327^{\mathrm{T}}$-inoculated seedlings of Glycine max, Trifolium pratense, Medicago sativa, Pisum sativum, Melilotus albus, Amorpha fruticosa, Lespedeza cuneata, Dunbaria rotundifolia or Vicia sepium. 


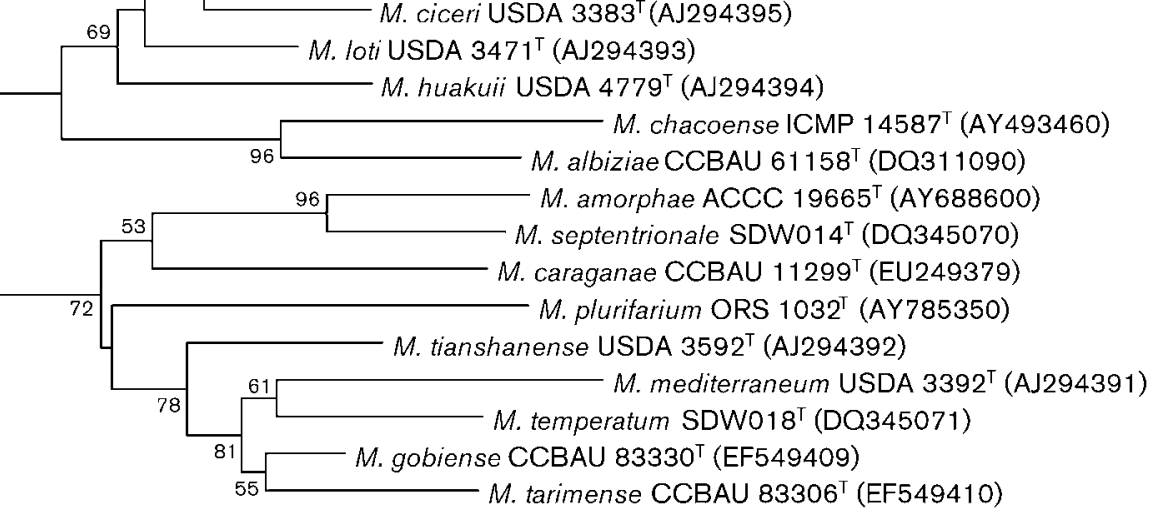

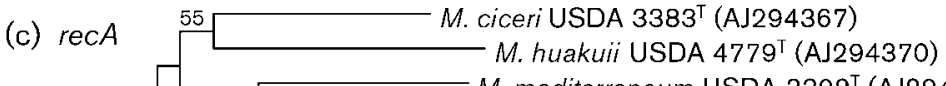

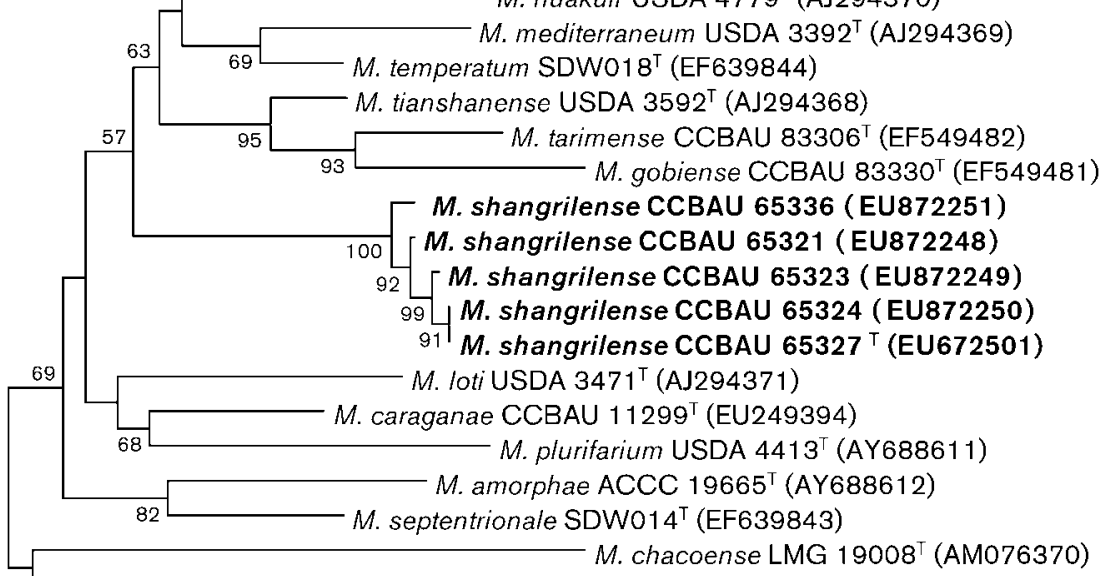
M. chacoense LMG $19008^{\top}$ (AM076370

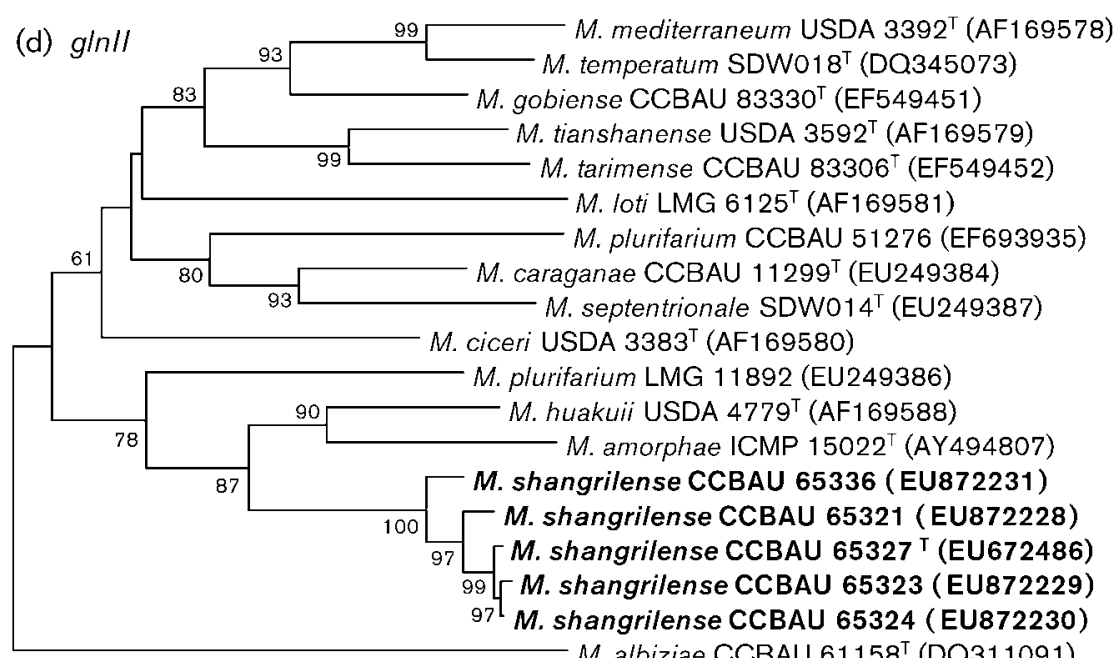
M. albiziae CCBAU $61158^{\top}(\mathrm{DQ} 311091)$

0.01

Fig. 1. Comparison of $16 \mathrm{~S}$ rRNA (a), atpD (b), $\operatorname{rec} A(\mathrm{c})$ and $g / n / l(\mathrm{~d})$ gene phylogenies, showing the relationships among the novel group (strain $C C B A U$ $65327^{\top}$ ) and defined species of the genus Mesorhizobium. Trees were reconstructed by using the neighbour-joining method with a Jukes-Cantor distance matrix. Bootstrap values (\%) are based on 1000 replicates and are shown at each node. Bars represent 0.005 or 0.01 expected changes per site. 
Table 1. Isolates and reference strains used in this study

\begin{tabular}{|c|c|c|c|}
\hline Strain & Host plant & Geographical origin/Altitude* & Reference \\
\hline \multicolumn{4}{|c|}{ Mesorhizobium shangrilense sp. nov. } \\
\hline CCBAU $65327^{\mathrm{T}}$ & Caragana bicolor & Deqin, Yunnan, China/3653 m & This study \\
\hline CCBAU 65323 & Caragana bicolor & Zhongdian, Yunnan, China/3267 m & This study \\
\hline CCBAU 65324 & Caragana bicolor & Zhongdian, Yunnan, China/3267 m & This study \\
\hline CCBAU 65336 & Caragana erinacea & Zhongdian, Yunnan, China/3399 m & This study \\
\hline M. loti NZP $2213^{\mathrm{T}}$ & Lotus corniculatus & New Zealand & Jarvis et al. (1997) \\
\hline M. ciceri USDA $3383^{\mathrm{T}}$ & Cicer arietinum & Spain & Nour et al. (1994) \\
\hline M. tianshanense CCBAU $3306^{\mathrm{T}}$ & Glycyrrhiza pallidiflora & Xinjiang, China & Chen et al. (1995) \\
\hline M. septentrionale SDW $014^{\mathrm{T}}$ & Astragalus adsurgens & Liaoning, China & Gao et al. (2004) \\
\hline M. temperatum SDW $018^{\mathrm{T}}$ & Astragalus adsurgens & Liaoning, China & Gao et al. (2004) \\
\hline M. plurifarium LMG $11892^{\mathrm{T}}$ & Acacia senegal & Senegal & de Lajudie et al. (1998) \\
\hline M. caraganae CCBAU $11299^{\mathrm{T}}$ & Caragana microphylla & Liaoning, China & Guan et al. (2008) \\
\hline M. albiziae CCBAU $61158^{\mathrm{T}}$ & Albizia kalkora & Sichuan, China & Wang et al. (2007) \\
\hline M. gobiense CCBAU $83330^{\mathrm{T}}$ & Oxytropis glabra & Xinjiang, China & Han et al. (2008) \\
\hline M. tarimense CCBAU $83306^{\mathrm{T}}$ & Lotus frondosus & Xinjiang, China & Han et al. (2008) \\
\hline
\end{tabular}

${ }^{\star}$ Deqin and Zhongdian are counties of Yunnan Province.

As a standard method for species definition (Graham et al., 1991; Wayne et al., 1987), DNA-DNA hybridization was performed between the representative strain CCBAU $65327^{\mathrm{T}}$ and other strains in the group and reference strains with $16 \mathrm{~S}$ rRNA gene sequence similarities higher than $97 \%$, using Marmur's method for total DNA isolation (Marmur, 1961) and the renaturation-rate technology described previously (De Ley et al., 1970). All experiments were performed three times and mean DNA relatedness values are reported. In this experiment, the standard deviation varied from 2.31 to $7.16 \%$ with a mean of $4.05 \%$. The results summarized in Supplementary Table S1 showed that the five Caragana rhizobial strains formed a genomic species sharing DNA relatedness greater than $88.5 \%$, while the DNA relatedness ranged from 9.5 to $27.5 \%$ (Supplementary Table S1) between CCBAU $65327^{\mathrm{T}}$ and reference strains for defined Mesorhizobium species, suggesting that the novel group was a distinct genomic species in the genus Mesorhizobium. The $\mathrm{G}+\mathrm{C}$ content of DNA was measured using the thermal denaturation method of De Ley (1970) using Escherichia coli K-12 as standard. The $\mathrm{G}+\mathrm{C}$ content range of the five strains was 60.82-61.59 mol\%, and that of CCBAU $65327^{\mathrm{T}}$ was found to be $61.37 \mathrm{~mol} \%\left(T_{\mathrm{m}}\right)$, which is within the range reported for Mesorhizobium (59-64 mol\%) (Jarvis et al., 1997).

Colony morphology of the isolates as well as morphology of Hucker's Gram- and Schaeffer-Fulton's spore-stained smears were examined. Phenotypic features of the novel group were determined in comparison with related Mesorhizobium species according to the method described by Gao et al. (1994). Tested features included the utilization of sole carbon and nitrogen sources, resistance to antibiotics and chemical dyes, tolerance of $\mathrm{NaCl}$ and $\mathrm{pH}$ and temperature ranges for growth (Gao et al., 1994). Biochemical tests including catalase and oxidase production, methyl red and Voges-Proskauer reactions and hydrolysis of casein, gelatin, starch, DNA and Tween 80 were performed according to Smibert \& Krieg (1994). Production of hydrogen sulfide from cysteine and production of indole from tryptophan were examined as described by Barrow \& Feltham (2003). Distinctive features of the novel group are shown in Table 2 and more features are presented in the subsequent description of the novel species.

Analysis of cellular fatty acids has become a useful method to characterize and identify microbes, especially in the study of Mesorhizobium species (Schutter \& Dick, 2000; Tighe et al., 2000). In this study, the strains were grown on YMA medium $\left(\mathrm{pH} \mathrm{7.0)}\right.$ for $72 \mathrm{~h}$ at $28{ }^{\circ} \mathrm{C}$ and then approximately $40 \mathrm{mg}$ well-grown cells was harvested. The extraction, preparation and separation of fatty acid methyl esters for strain CCBAU $65327^{\mathrm{T}}$ were performed according to methods described by Sasser (1990). Identification of these fatty acid methyl esters was completed using the MIDI Sherlock Microbial Identification System. The comparison of fatty acid profiles between CCBAU $65327^{\mathrm{T}}$ and the other defined Mesorhizobium species (including the most recently described species Mesorhizobium caraganae, Mesorhizobium gobiense and Mesorhizobium tarimense) is shown in Supplementary Table S2. Strain CCBAU $65327^{\mathrm{T}}$ 
Table 2. Distinctive features of strain CCBAU $65327^{\top}$ and the closest related Mesorhizobium species

Strain: 1 , M. shangrilense sp. nov. CCBAU $65327^{\mathrm{T}} ; 2$, M. ciceri USDA $3383^{\mathrm{T}}$; 3, M. loti NZP 2213 ${ }^{\mathrm{T}}$; 4, M. tianshanense CCBAU $3306^{\mathrm{T}}$; 5, M. septentrionale SDW0 $14^{\mathrm{T}}$. + , Positive; - , negative. All data are from this study. The concentration of carbon and nitrogen sources is $0.1 \%$ $(\mathrm{w} / \mathrm{v})$.

\begin{tabular}{|c|c|c|c|c|c|}
\hline Character & 1 & 2 & 3 & 4 & 5 \\
\hline \multicolumn{6}{|l|}{ Substrates used as sole carbon source } \\
\hline meso-Erythritol & - & + & + & - & - \\
\hline Glucose & + & - & + & + & + \\
\hline Sodium DL-malate & + & - & + & + & - \\
\hline D-Mannose & + & + & + & + & - \\
\hline Sodium pyruvate & + & - & + & + & - \\
\hline L-Rhamnose & + & - & + & - & + \\
\hline Sodium citrate & + & + & - & + & - \\
\hline Sodium succinate & + & + & + & + & - \\
\hline Trehalose & + & - & + & + & + \\
\hline \multicolumn{6}{|l|}{ Substrates used as sole nitrogen source } \\
\hline L-Aspartic acid & + & - & + & + & - \\
\hline Hypoxanthine & + & + & + & + & - \\
\hline L-Phenylalanine & + & - & + & + & + \\
\hline L-Valine & + & - & + & + & - \\
\hline L-Methionine & + & + & + & - & + \\
\hline \multicolumn{6}{|l|}{ Resistance to: } \\
\hline Ampicillin $\left(50 \mu \mathrm{g} \mathrm{ml}^{-1}\right)$ & + & + & + & - & + \\
\hline Kanamycin sulfate $\left(5 \mu \mathrm{g} \mathrm{ml}^{-1}\right)$ & + & + & + & + & - \\
\hline Kanamycin sulfate $\left(50 \mu \mathrm{g} \mathrm{ml}^{-1}\right)$ & - & - & + & - & - \\
\hline Streptomycin sulfate $\left(5 \mu \mathrm{g} \mathrm{ml}^{-1}\right)$ & + & + & + & + & + \\
\hline Streptomycin sulfate $\left(50 \mu \mathrm{g} \mathrm{ml}^{-1}\right)$ & + & - & + & - & - \\
\hline Bacitracin $\left(300 \mu \mathrm{g} \mathrm{ml}^{-1}\right)$ & + & + & - & - & + \\
\hline Erythromycin $\left(50 \mu \mathrm{g} \mathrm{ml}^{-1}\right)$ & - & + & - & - & - \\
\hline Chloramphenicol $\left(5 \mu \mathrm{g} \mathrm{ml}^{-1}\right)$ & + & - & + & + & + \\
\hline Bismarck brown $(0.1 \%)$ & - & - & + & - & + \\
\hline Erythrosine bluish (0.1\%) & - & + & - & - & - \\
\hline Sodium deoxycholate $(0.1 \%)$ & - & + & + & + & + \\
\hline \multicolumn{6}{|l|}{ Growth in/at: } \\
\hline $\mathrm{NaCl}(2 \%)$ & + & - & + & + & - \\
\hline $\mathrm{NaCl}(3 \%)$ & + & - & - & - & - \\
\hline pH 9.0 & + & - & + & + & - \\
\hline pH 10.0 & + & - & + & + & - \\
\hline
\end{tabular}

was clearly placed in the genus Mesorhizobium because it lacked $\mathrm{C}_{20: 3} \omega 6,9,12 c$ and summed feature 3 (same as summed feature 2 in this study, referring to $C_{12: 0}$, unknown ECL 10.928, iso- $\mathrm{C}_{16: 1} 1$ and/or $\mathrm{C}_{14: 0} 3-\mathrm{OH}$; Supplementary Table S2) and possessed iso- $\mathrm{C}_{17: 0}$ fatty acids (Tighe et al., 2000). Strain CCBAU $65327^{\mathrm{T}}$ could be distinguished from the other Mesorhizobium species because it contained a higher concentration of $\mathrm{C}_{19: 0}$ cyclo $\omega 8 c$.

Based on the results obtained in this study, we believe that the five strains represent a novel species in the genus Mesorhizobium that could be differentiated by SDS-PAGE of cellular soluble proteins, fatty acid profiles, phenotypic characteristics, DNA relatedness and sequencing of atpD, glnII, recA, nodC and nifH genes. As a result, we propose the name Mesorhizobium shangrilense sp. nov. for this group with CCBAU $65327^{\mathrm{T}}$ as type strain.

\section{Description of Mesorhizobium shangrilense sp. nov.}

Mesorhizobium shangrilense (shan.gri.len'se. N.L. neut. adj. shangrilense pertaining to Shangri-La, the name of the area covering the sites where the first strains were isolated).

Gram-stain-negative, aerobic, non-spore-forming rods, 0.3$0.6 \mu \mathrm{m}$ wide by $1-3 \mu \mathrm{m}$ long. Colonies on YMA medium are circular, convex, white, opaque and usually $1-2 \mathrm{~mm}$ in diameter after 5-7 days at $28{ }^{\circ} \mathrm{C}$. Growth occurs between 10 and $37{ }^{\circ} \mathrm{C}$ with an optimum at $28{ }^{\circ} \mathrm{C}$. The $\mathrm{pH}$ range is $5-10$ with an optimum at $\mathrm{pH}$ 7.0. Can grow on YMA in the presence of $3 \% \mathrm{NaCl}$. Produces catalase and oxidase but not L-phenylalaninase or urease. Methyl blue, but not nitrate or Nile blue is reduced. Acid production in litmus milk. No hydrolysis of gelatin, casein, starch, DNA or Tween 80 . Indole but not $\mathrm{H}_{2} \mathrm{~S}$ is produced and the Voges-Proskauer and methyl red reactions are negative. Resistant to $\left(\mu \mathrm{g} \mathrm{ml}^{-1}\right)$ ampicillin (50), kanamycin sulfate (5), neomycin sulfate (5), streptomycin sulfate (50), bacitracin (300), erythromycin (5) and chloramphenicol (5). Can use D-arabinose, Dfructose, D-mannose, D-sorbitol, D-xylose, glucose, inulin, inositol, maltose, sodium citrate, sodium malate, L-rhamnose, sodium pyruvate, sodium succinate, sucrose and trehalose as sole carbon sources, and DL- $\alpha$-aminopropionic acid, hypoxanthine, L-aspartic acid, L-glutamic acid, Larginine, L-hydroxyproline, L-methionine, L-phenylalanine, L-threonine and L-valine as sole nitrogen sources. Cannot use vanillic acid, adipic acid, calcium gluconate, calcium malonate, D-amygdalin, D-galactose, melezitose, melibiose, D-ribose, turanose, dextrin, DL-asparagine, dulcitol, glycine, L-arginine, L-methionine, L-proline, meso-erythritol, raffinose, salicin, sodium D-gluconate, sodium acetate, sodium formate, sodium tartrate, sorbose, starch, sucrose or syringic acid as sole carbon sources, and cannot use D-threonine, DLalanine, glycine or L-isoleucine as sole nitrogen sources. DNA G + C content of the type strain is $61.37 \mathrm{~mol} \%\left(T_{\mathrm{m}}\right)$.

The type strain, CCBAU $65327^{\mathrm{T}}\left(=\mathrm{LMG} 24762^{\mathrm{T}}=\right.$ HAMBI $\left.3050^{\mathrm{T}}\right)$, was isolated from root nodules of Caragana bicolor growing in Deqin city, Yunnan Province, China.

\section{Acknowledgements}

This work was financed by the National Natural Science Foundation of China (project no. 30400001), The National Program for Basic S \& $\mathrm{T}$ Platform Construction (no. 2005DKA21201) and The Natural Science Foundation of Beijing (6053024). We thank Professor Janet I. Sprent for improvement of the manuscript.

\section{References}

Barrow, G. I. \& Feltham, R. K. A. (2003). Cowan and Steel's Manual for the Identification of Medical Bacteria, 3rd edn. Cambridge: Cambridge University Press. 
Chen, W. X., Wang, E. T., Wang, S. Y., Li, Y. B., Chen, X. Q. \& Li, Y. (1995). Characteristics of Rhizobium tianshanense sp. nov., a moderately and slowly growing root nodule bacterium isolated from an arid saline environment in Xinjiang, People's Republic of China. Int J Syst Bacteriol 45, 153-159.

Chen, W. F., Guan, S. H., Zhao, C. T., Yan, X. R., Man, C. X., Wang, E. T. \& Chen, W. X. (2008). Different Mesorhizobium species associated with Caragana carry similar symbiotic genes and have common host ranges. FEMS Microbiol Lett 283, 203-209.

de Lajudie, P., Willems, A., Nick, G., Moreira, F., Molouba, F., Hoste, B., Torck, U., Neyra, M., Collins, M. D. \& other authors (1998). Characterization of tropical tree rhizobia and description of Mesorhizobium plurifarium sp. nov. Int J Syst Bacteriol 48, 369-382.

De Ley, J. (1970). Reexamination of the association between melting point, buoyant density, and chemical base composition of deoxyribonucleic acid. J Bacteriol 101, 738-754.

De Ley, J., Cattoir, H. \& Reynaerts, A. (1970). The quantitative measurement of DNA hybridization from renaturation rates. Eur $J$ Biochem 12, 133-142.

Fan, S. Y., Freedman, B. \& Gao, J. X. (2007). Potential environmental benefits from increased use of bioenergy in China. Environ Manage 40, 504-515.

Felsenstein, J. (1985). Confidence limits on phylogenies: an approach using the bootstrap. Evolution 39, 783-791.

Gao, J. L., Sun, J. G., Li, Y., Wang, E. T. \& Chen, W. X. (1994). Numerical taxonomy and DNA relatedness of tropical rhizobia isolated from Hainan province, China. Int J Syst Bacteriol 44, 151-158.

Gao, J. L., Turner, S. L., Kan, F. L., Wang, E. T., Tan, Z. Y., Qiu, Y. H., Gu, J., Terefework, Z., Young, J. P. \& other authors (2004). Mesorhizobium septentrionale sp. nov. and Mesorhizobium temperatum sp. nov., isolated from Astragalus adsurgens growing in the northern regions of China. Int J Syst Evol Microbiol 54, 2003-2012.

Gaunt, M. W., Turner, S. L., Rigottier-Gois, L., Lloyd-Macgilp, S. A. \& Young, J. P. W. (2001). Phylogenies of atpD and recA support the small subunit rRNA-based classification of rhizobia. Int J Syst Evol Microbiol 51, 2037-2048.

Graham, P. H., Sadowsky, M. J., Keyser, H. H., Barnet, Y. M., Bradley, R. S., Cooper, J. E., De Ley, D. J., Jarvis, B. D. W., Roslycky, E. B. \& other authors (1991). Proposed minimal standards for the description of new genera and species of root- and stem-nodulating bacteria. Int J Syst Bacteriol 41, 582-587.

Guan, S. H., Chen, W. F., Wang, E. T., Lu, Y. L., Yan, X. R., Zhang, X. X. \& Chen, W. X. (2008). Mesorhizobium caraganae sp. nov., a novel rhizobial species nodulated with Caragana spp. in China. Int J Syst Evol Microbiol 58, 2646-2653.

Han, T. X., Han, L. L., Wu, L. J., Chen, W. F., Sui, X. H., Gu, J. G., Wang, E. T. \& Chen, W. X. (2008). Mesorhizobium gobiense sp. nov. and Mesorhizobium tarimense sp. nov., isolated from wild legumes growing in desert soils of Xinjiang, China. Int J Syst Evol Microbiol 58, 2610-2618.

Haukka, K., Lindstrom, K. \& Young, J. P. W. (1998). Three phylogenetic groups of nodA and nifH genes in Sinorhizobium and Mesorhizobium isolates from leguminous trees growing in Africa and Latin America. Appl Environ Microbiol 64, 419-426.

Jarvis, B. D. W., Van Berkum, P., Chen, W. X., Nour, S. M., Fernandez, M. P., Cleyet-Marel, J. C. \& Gillis, M. (1997). Transfer of Rhizobium loti, Rhizobium huakuii, Rhizobium ciceri, Rhizobium mediterraneum, and Rhizobium tianshanense to Mesorhizobium gen. nov. Int J Syst Bacteriol 47, 895-898.

Jukes, T. H. \& Cantor, C. R. (1969). Evolution of protein molecules. In Mammalian Protein Metabolism, vol. 3, pp. 21-132. Edited by $\mathrm{H}$. N. Munro. New York: Academic Press.
Laguerre, G., Nour, S. M., Macheret, V., Sanjuan, J., Drouin, P. \& Amarger, N. (2001). Classification of rhizobia based on nodC and nifH gene analysis reveals a close phylogenetic relationship among Phaseolus vulgaris symbionts. Microbiology 147, 981-993.

Liu, J., Wang, E. T. \& Chen, W. X. (2005). Diverse rhizobia associated with woody legumes Wisteria sinensis, Cercis racemosa and Amorpha fruticosa grown in the temperate zone of China. Syst Appl Microbiol 28, 465-477.

Lu, Y. L., Chen, W. F., Wang, E. T., Guan, S. H., Yan, X. R. \& Chen, W. X. (2009). Genetic diversity and biogeography of rhizobia associated with Caragana species in three ecological regions of China. Syst Appl Microbiol 32, 351-361.

Marmur, J. (1961). A procedure for the isolation of deoxyribonucleic acid from microorganisms. J Mol Biol 3, 208-218.

Nour, S. M., Fernandez, M. P., Normand, P. \& Cleyet-Marel, J. C. (1994). Rhizobium ciceri sp. nov., consisting of strains that nodulate chickpeas (Cicer arietinum L.). Int J Syst Bacteriol 44, 511-522.

Saitou, N. \& Nei, M. (1987). The neighbor-joining method: a new method for reconstructing phylogenetic trees. Mol Biol Evol 4, 406425.

Sasser, M. (1990). Identification of bacteria by gas chromatography of cellular fatty acids, MIDI Technical Note 101. Newark, DE: MIDI Inc.

Schutter, M. E. \& Dick, R. P. (2000). Comparison of fatty acid methyl ester (FAME) methods for characterizing microbial communities. Soil Sci Soc Am J 64, 1659-1668.

Smibert, R. M. \& Krieg, N. R. (1994). Phenotypic characterization. In Methods for General and Molecular Bacteriology, pp. 607-654. Edited by P. Gerhardt, R. G. E. Murray, W. A. Wood \& N. R. Krieg. Washington, DC: American Society for Microbiology.

Su, Y. Z., Zhang, T. H., Li, Y. L. \& Wang, F. (2005). Changes in soil properties after establishment of Artemisia halodendron and Caragana microphylla on shifting sand dunes in semiarid Horqin sandy land, northern China. Environ Manage 36, 272-281.

Tamura, K., Dudley, J., Nei, M. \& Kumar, S. (2007). MEGA4: molecular evolutionary genetics analysis (MEGA) software version 4.0. Mol Biol Evol 24, 1596-1599.

Tan, Z. Y., Xu, X. D., Wang, E. T., Gao, J. L., Martinez-Romero, E. \& Chen, W. X. (1997). Phylogenetic and genetic relationships of Mesorhizobium tianshanense and related rhizobia. Int J Syst Bacteriol 47, 874-879.

Tighe, S. W., de Lajudie, P., Dipietro, K., Lindstrom, K., Nick, G. \& Jarvis, B. D. W. (2000). Analysis of cellular fatty acids and phenotypic relationships of Agrobacterium, Bradyrhizobium, Mesorhizobium, Rhizobium and Sinorhizobium species using the Sherlock Microbial Identification System. Int J Syst Evol Microbiol 50, 787-801.

Turner, S. L. \& Young, J. P. W. (2000). The glutamine synthetases of rhizobia: phylogenetics and evolutionary implications. Mol Biol Evol 17, 309-319.

Ueda, T., Suga, Y., Yahiro, N. \& Matsuguchi, T. (1995). Phylogeny of Sym plasmids of rhizobia by PCR-based sequencing of a nodC segment. J Bacteriol 177, 468-472.

Vauterin, L. \& Vauterin, P. (1992). Computer-aided objective comparison of electrophoresis patterns for grouping and identification of microorganisms. Eur Microbiol 1, 37-41.

Velazquez, E., Igual, J. M., Willems, A., Fernández, M. P., Muñoz, E., Mateos, P. F., Abril, A., Toro, N., Normand, P. \& other authors (2001). Mesorhizobium chacoense sp. nov., a novel species that nodulates Prosopis alba in the Chaco Arido region (Argentina). Int J Syst Evol Microbiol 51, 1011-1021.

Vincent, J. M. (1970). The cultivation, isolation and maintenance of rhizobia. In A Manual for the Practical Study of the Root-Nodule 
Bacteria, pp. 1-13. Edited by J. M. Vincent. Oxford: Blackwell Scientific.

Wang, E. T., van Berkum, P., Sui, X. H., Beyene, D., Chen, W. X. \& Martinez-Romero, E. (1999). Diversity of rhizobia associated with Amorpha fruticosa isolated from Chinese soils and description of Mesorhizobium amorphae sp. nov. Int J Syst Bacteriol 49, 51-65.

Wang, F. Q., Wang, E. T., Liu, J., Chen, Q., Sui, X. H., Chen, W. F. \& Chen, W. X. (2007). Mesorhizobium albiziae sp. nov., a novel bacterium that nodulates Albizia kalkora in a subtropical region of China. Int J Syst Evol Microbiol 57, 1192-1199.
Wayne, L. G., Brenner, D. J., Colwell, R. R., Grimont, P. A. D., Kandler, O., Krichevsky, M. I., Moore, L. H., Moore, W. E. C., Murray, R. G. E. \& other authors (1987). International Committee on Systematic Bacteriology. Report of the ad hoc committee on reconciliation of approaches to bacterial systematics. Int J Syst Bacteriol 37, 463-464.

Yan, X. R., Chen, W. F., Fu, J. F., Lu, Y. L., Xue, C. Y., Sui, X. H., Li, Y., Wang, E. T. \& Chen, W. X. (2007). Mesorhizobium spp. are the main microsymbionts of Caragana spp. grown in Liaoning Province of China. FEMS Microbiol Lett 271, 265-273.

Zhang, M. L. (2005). A dispersal and vicariance analysis of the genus Caragana Fabr. J Integr Plant Biol 47, 897-904. 